\title{
EFFECT OF MARJORAM (Marjorana hortensis) OR SAGE (Salvia officinalis) ADDITIVES ON GROWTH PERFORMANCE AND FEED UTILIZATION OF TILAPIA HYBRID (Oreochromis niloticus $\times$ Oreochromis aureus) MONOSEX FINGERLINGS. \\ El-Kholy, Kh. F. \\ Animal Production Research Institute, Agricultural Research Center, Ministry of Agriculture and Land Reclamation, Dokki, Giza, Egypt.
}

\section{ABSTRACT}

The response of tilapia hybrid (Oreochromis niloticus $\times$ Oreochromis aureus) to dietary herbs plants supplement with respect to growth performance and feed utilization through feeding experiments was investigated. Seven tilapia hybrid fingerlings treatments ( 45 fingerlings each, as average initial body weight $3.03 \pm 0.01 \mathrm{~g}$ ) were used at period 90 days in closed system. Seven dietary approximately isonitrogenous ( $30.63 \pm 0.33 \%$ crude protein) and iso-caloric (4757 $\pm 39 \mathrm{kcal} \mathrm{GE} / \mathrm{kg}$ diet) were formulated, fed to three aquaria for each treatment (diet). Medicinal herbs additives of three levels from marjoram (Majorana hortensis) or sage (Salvia officinalis L.) being 150,300 and $600 \mathrm{mg} / \mathrm{kg}$ diet, respectively. The obtained results revealed that fish groups fed the low levels $(150 \mathrm{mg} / \mathrm{Kg})$ of either marjoram or sage showed high response in final body weight, total weight gain, SGR (\%/day) and RGR (\%), followed by the moderate levels $(300 \mathrm{mg} / \mathrm{Kg}$ ) and finally the high levels of the additives $(600 \mathrm{mg} / \mathrm{Kg})$ compared to fish fed the control diet. Also, it is noted that herbal plant improve in feed utilization parameters of tilapia hybrid fingerlings, but it was declined when the level of herbal plant increased. Fish groups fed diets containing sage reflected high values of fat productive values (\%) in the low level of additives and declined with increasing the level of sage in the diet. On the other hand, fish groups fed marjoram showed that declined FPV (\%) with increasing the level of the marjoram used.

Therefore, it could be concluded that tilapia hybrid (Oreochromis niloticus $\times$ Oreochromis aureus) fingerlings achieve increasing by 150 and $300 \mathrm{mg} / \mathrm{kg}$ dietary addition of marjoram or sage herbs, respectively.

Keywords: Nile tilapia hybrid, medicinal herbs, marjoram, sage, growth performance, feed utilization.

\section{INTRODUCTION}

Medicinal herbs to use in human feeding are well known for thousands of years such as Egypt, India and China. Recently, there has been increasing interest in the use of medicinal plants, therefore, the plant kingdom has become a target for the search by multinational drug and biologically active lead compounds (Evans, 1996).

In aquaculture, there are many studies reporting a variety of substances including synthetic (Rao et al., 2006), bacterial (Goetz et al., 2004), animal and plant products (Ardo et al., 2008) can be used as immunestimulants to enhance non-specific immune system of cultured fish species. Some medicinal plants are rich sources of compounds like volatile oils, saponins, phenolics, tannins, alkaloids, polysaccharides and polypeptides. These natural plant products have various activities like 
antistress, appetizer, tonic, antimicrobial and immunostimulants (Citarasu et al., 2002, 2003). Consequently, scores of plant extract have been tested and used under control of bacterial and viral diseases (Pachanawan et al., 2008). In addition, many herbs have been used as spices and medicinal additives in fish (Lee et al., 2001 and El-Dakar et al., 2007) and shrimp (El-Dakar et al., 2005) as growth promoters' substances.

Using medicinal herbs as growth promoters is becoming useful for fish feeding rather than classic chemical feed additives because of the accumulative effect of the chemical compounds which induced deterrent effects on human health (El-Dakar et al., 2008). The most recent studies showed successful use of spices and natural herbs in fish nutrition including marjoram, basil, licorice roots, black seeds, peppermint, and fenugreek seeds (Abd El-Maksoud et al., 2002; Abd El-Monem et al., 2002; Sakr, 2003; Shalaby et al., 2003; El-Dakar et al., 2004a,b and Shalaby, 2004).

Among the effective spices, marjoram (Majorana hortensis Moench) commonly known as "sweet marjoram" is a classified of the family Lamiaceae (Labiatate). It is a perennial herb native to Cyprus and eastern Mediterranean countries (Egypt, Greeks and Romans) reported by (Tainter and Grenis, 1993). Marjoram is well known for its medicinal and insecticidal values. The plant is also reported to possess anticancer (Hartweel, 1969), antioxidant (ElGhorab et al., 2004) and antifungal properties (Pruthi, 1980).

The leaves of sage (Salvia officinalis L.) are well known for their antioxidative properties (Hohmann et al., 1999), used in the food processing industry but applicable also to the area of human health (Pearson et al., 1997). Salvia officinalis is reported to have a wide range of biological activities, such as anti-bacterial, fungistatic, virustatic, astringent, eupeptic and anti-hydrotic effects (Cherevatyî et al., 1980 and Farag et al., 1986). In addition, there are some reports concerning the hypoglycemic effects of sage, from the family Lamiaceae, in Iranian folk medicine (Omidbeygi, 1997 and Zargari, 1997).

The objectives of the present study aimed to evaluate the effects of marjoram and sage leaves as additions at different levels; 0, 150, 300, and $600 \mathrm{mg} / \mathrm{Kg}$ diet; into tilapia hybrid (Oreochromis niloticus $\times$ Oreochromis aureus) monosex fingerlings on growth performance, feed utilization and whole chemical of body composition.

\section{MATERIALS AND METHODS}

\section{Experimental system and fish}

The present investigation was carried out at Fish laboratory, Utilization of by-Products Department, Animal Production Research Institute, Ministry of Agriculture and Land Reclamation, Giza, Egypt. Monosex tilapia hybrid (Oreochromis niloticus $\times$ Oreochromis aureus) fingerlings with average weight approximately $1 \mathrm{~g}$. They were purchased from private hatchery in Kafer El Shaikh Governorate then transferred to the fish lab. They were acclimation and kept in plastic containers $(500 \mathrm{l})$ with recirculated and aerated water at $22-24{ }^{\circ} \mathrm{C}$ for a this period to assess their disease-free health status during adaption to the experimental fishs to the ambient laboratory condition until 
they reached a body weight of approximately $3 \mathrm{~g}$. During the acclimation period, the fingerlings were fed diet containing $30 \% \mathrm{CP}$. The fingerlings were randomly distributed in triplicates/treatment. The feeding trial was carried out in glass aquaria $(60 \mathrm{l})$ through a warm water recirculating system. Dechlorinated tap water was recirculated through biological and mechanical filters. Water exchange rate for the system was approximately $10 \%$ of total volume per every day. Each aquarium was supplied with oxygen until saturation about $80 \%$.

\section{Experimental procedure and feeding experiment}

Marjoram (Marjorana hortensis) and sage (Salvia officinalis) leaves were purchased from local market. They were cleaned, shadow dried at $25^{\circ} \mathrm{C}$, grinding and the powders then kept separately in nylon bags in a deep freezer until prepared of experiment diets. Seven experimental diets were formulated to contain three levels of marjoram or sage additions to the control diet $\left(\mathrm{H}_{1}\right)$. Diets from $\mathrm{H}_{2}$ to $\mathrm{H}_{7}$ contained appropriate quantities 150,300 and $600 \mathrm{mg} / \mathrm{kg}$ diet of either marjoram or sage, respectively. All tested diets formulated to be iso-nitrogenous (30.63 $\pm 0.33 \%$ crude protein) and isocaloric $(4757 \pm 39 \mathrm{kcal} \mathrm{GE} / \mathrm{kg}$ diet). Formulation and proximate analysis of the experimental diets are presented in Table (1).

Table 1: Formulation and proximate analysis of the experimental diets (on \%DM) fed to tilapia hybrid (Oreochromis niloticus $\times 0$. aureus) monosex fingerlings.

\begin{tabular}{|c|c|c|c|c|c|c|c|}
\hline & \multicolumn{7}{|c|}{ Experimental diets } \\
\hline & Control & \multicolumn{3}{|c|}{ Marjoram } & \multicolumn{3}{|c|}{ Sage } \\
\hline Ingredients (\%) & $\mathrm{H}_{1}$ & $\mathrm{H}_{2}$ & $\mathrm{H}_{3}$ & $\mathrm{H}_{4}$ & $\mathrm{H}_{5}$ & $\mathrm{H}_{6}$ & $\mathrm{H}_{7}$ \\
\hline Yellow corn & 46.75 & 46.60 & 46.45 & 46.15 & 46.60 & 46.45 & 46.15 \\
\hline Fish meal (72\%) & 22.75 & 22.75 & 22.75 & 22.75 & 22.75 & 22.75 & 22.75 \\
\hline Soybean meal (40 \%) & 24.00 & 24.00 & 24.00 & 24.00 & 24.00 & 24.00 & 24.00 \\
\hline Corn oil & 3.50 & 3.50 & 3.50 & 3.50 & 3.50 & 3.50 & 3.50 \\
\hline Dried yeast & 1.00 & 1.00 & 1.00 & 1.00 & 1.00 & 1.00 & 1.00 \\
\hline Vit. \& Min. mixture ${ }^{\star}$ & 2.00 & 2.00 & 2.00 & 2.00 & 2.00 & 2.00 & 2.00 \\
\hline Marjoram & - & 0.15 & 0.30 & 0.60 & - & - & - \\
\hline Sage & - & - & - & - & 0.15 & 0.30 & 0.60 \\
\hline Total & 100 & 100 & 100 & 100 & 100 & 100 & 100 \\
\hline \multicolumn{8}{|l|}{ Proximate analysis (\%) } \\
\hline Dry matter (DM) & 93.83 & 93.07 & 92.39 & 93.09 & 91.70 & 92.30 & 92.32 \\
\hline Crude protein (CP) & 30.66 & 30.36 & 30.36 & 30.55 & 30.94 & 30.65 & 30.87 \\
\hline Ether extract (EE) & 9.89 & 10.39 & 9.61 & 10.56 & 10.24 & 10.53 & 11.02 \\
\hline Crude fiber (CF) & 2.45 & 1.67 & 1.24 & 1.51 & 2.09 & 1.21 & 1.37 \\
\hline Ash & 7.71 & 6.95 & 7.24 & 7.62 & 7.09 & 8.38 & 7.86 \\
\hline $\mathrm{NFE}^{\star \star}$ & 49.29 & 50.63 & 51.55 & 49.76 & 49.64 & 49.23 & 48.88 \\
\hline GE (Kcal/Kg) *** & 4737 & 4789 & 4735 & 4714 & 4785 & 4744 & 4796 \\
\hline C/P ratio & 154.50 & 157.74 & 155.96 & 154.30 & 154.65 & 154.78 & 155.36 \\
\hline \multicolumn{8}{|c|}{ 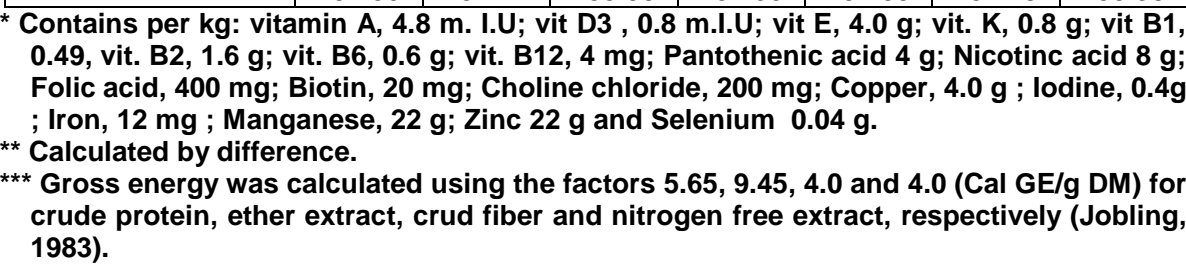 } \\
\hline
\end{tabular}


Before starting the experiment, taken 50 fingerlings from the population as sampled for determination of initial body proximate composition. At the beginning of the experiment, fish were individually weighed thereafter, they were bulk, weighed weekly and the feed amounts were adjusted for the subsequent week.

The average body weight of hybrid tilapia (Oreochromis niloticus $\times$ Oreochromis aureus) was $3.03 \mathrm{~g}$. The fish were divided into seven treatments $\left(H_{1}\right.$ to $H_{7}$ ), each treatments contained three replicates (15 fingerlings in each replicate). During the experimental period, the fish were fed with their respective diets at a rate of $3 \%$ of their body mass per day. The daily ration was subdivided into two amounts at 0900 and $1600 \mathrm{hrs}$. A record was kept of the amount of feed consumed by the fish in each aquarium. The experimental period was 90 days. At the end, the experimental fish were sacrificed and kept at $-20{ }^{\circ} \mathrm{C}$ until analyzed for body composition as whole.

\section{Sampling and analytical procedures:}

All fish were weighed at the start of trial. Whole body composition was determined in a pooled sample of 50 fish at the beginning and in pools of 8 fish per replicate at the end of the growth trial. The experimental diets and the fish carcass at the beginning and the end of the experiment were analyzed for proximate composition according to methods of A.O.A.C (2000). Gross energy (GE) contents of all samples were calculated according to Jobling (1983) using the multiplication factors of 4.0; 5.65 and $9.45 \mathrm{cal} \mathrm{GE/g}$ for carbohydrate; protein and fat, respectively. Growth indexes were calculated as follows formulations:

- Total Weight gain (WG, g)=final body weight (g)-initial body weight $(\mathrm{g})$;

- Relative growth rate (RGR, \%) $=100 \times$ [final body weight (g)-initial body weight $(\mathrm{g})] /$ initial body weight $(\mathrm{g})$;

- Specific growth rate (SGR) $(\% /$ day $)=100 \times[\ln$ final body weight $(\mathrm{g})$-In initial body weight $(\mathrm{g})] /$ time of trial (days);

- Feed intake $(\mathrm{Fl}, \mathrm{g} /$ fish $)=$ Total dry matter feed consumed;

- $\quad$ Feed conversion ratio $(F C R)=$ feed intake $(\mathrm{g}) /$ weight gain $(\mathrm{g})$;

- Protein efficiency ratio $(P E R)=$ weight gain $(g) /$ protein intake $(g)$;

- Protein productive value (PPV, \%) $=100 \times[$ Retained protein $(\mathrm{g}) /$ protein intake $(\mathrm{g})]$;

- $\quad$ Fat productive value $(F P V, \%)=100 \times[$ Retained fat $(\mathrm{g}) /$ fat intake $(\mathrm{g})]$;

- Energy utilization (EU, \%) $=100 \times[$ Retained energy $(\mathrm{g}) /$ energy intake (kcal)].

Water quality

Temperature and oxygen concentration were measured daily, while $\mathrm{pH}$ and the concentrations of total ammonium nitrogen (TAN $=\mathrm{NH}_{4}{ }^{+}-\mathrm{N}+\mathrm{NH}_{3}{ }^{-}$ $\mathrm{N})$ and nitrite-nitrogen $\mathrm{NO}_{2}-\mathrm{N}$ were determined weekly. Water temperature was maintained at $24.1 \pm 1^{\circ} \mathrm{C}$. The oxygen concentration at the aquaria outflows did not drop below $4.6 \mathrm{mg} \mathrm{L}^{-1}$ and was measured by using Oxygen meter (Jan way model 9071). The total concentrations of ammonia-nitrogen and nitrite-nitrogen at the outflow of the rearing aquaria did not exceed 0.30 $\mathrm{mg} \mathrm{TAN} \mathrm{L}{ }^{-1}$ or $0.02 \mathrm{mg} \mathrm{NO}_{2}-\mathrm{N} \mathrm{L}^{-1}$, respectively. Water $\mathrm{pH}$ ranged from 7.9 to 
8.3. The $\mathrm{pH}$ and water temperature values were determined by digital temperature and $\mathrm{pH}$ meter (Orion model 720A, S/No 13062). The previous analytical methods were done according to American Public Health Association (APHA, 1992). During the study, but averages were within acceptable limits for tilapia fish growth and health (Boyd, 1990).

\section{Statistical analysis:}

Biological data obtained from the trial were expressed as mean \pm S.E and subjected to statistical evaluation using one-way analysis of variance (ANOVA) of the general liner model (GLM) using (SAS, 2002) statistical package. Means with significantly different $(P<0.05)$ were compared with Duncan's Multiple Range test (1955).

\section{RESULTS AND DISCUSSION}

Data on the growth performance of tilapia hybrid, including initial body weight (IBW), final body weight (FBW), total weight gain (WG), relative growth rate (RGR) and specific growth rate (SGR) are shown in Table (2). These parameters in fish treatments fed diets supplemented with herbs were significantly higher than fish fed the control diet. Within the type of the herbal plants, as the level of herbal plant increased in the diets, the positive effects in treatments decreased. Meanwhile, fish fed diet contained $150 \mathrm{mg} / \mathrm{Kg}$ sage $\left(\mathrm{H}_{5}\right)$ showed higher values $(\mathrm{P}>0.05)$ in the growth parameters compared with that contained $300 \mathrm{mg} / \mathrm{Kg}$ sage $\left(\mathrm{H}_{6}\right)$ and those fed marjoram diets or significant of diet contained $600 \mathrm{mg} / \mathrm{Kg}$ sage $\left(\mathrm{H}_{7}\right)$.

Table 2: Growth performance of tilapia hybrid (Oreochromis niloticus $\times$ $O$. aureus) fingerlings fed the experimental diets (Mean $\pm \mathrm{SE}$ ).

\begin{tabular}{|c|c|c|c|c|c|c|c|}
\hline & \multicolumn{7}{|c|}{ Experimental diets } \\
\hline \multirow[b]{2}{*}{ Item } & Control & \multicolumn{3}{|c|}{ Marjoram } & \multicolumn{3}{|c|}{ Sage } \\
\hline & $\mathrm{H}_{1}$ & $\mathrm{H}_{2}$ & $\mathrm{H}_{3}$ & $\mathrm{H}_{4}$ & $\mathrm{H}_{5}$ & $\mathrm{H}_{6}$ & $\mathrm{H}_{7}$ \\
\hline Initial body w & 3.03 & 3.03 & 3.04 & 3.01 & 3.02 & 3.03 & 3.02 \\
\hline IBW ( & \pm 0.01 & \pm 0.01 & \pm 0.02 & $0.01 \pm$ & $0.01 \pm$ & $0.02 \pm$ & $0.02 \pm$ \\
\hline Final body weight, & $12.19^{C}$ & $14.83^{\text {ab }}$ & $14.19^{\text {ab }}$ & $14.01^{\text {ab }}$ & $15.12^{\mathrm{a}}$ & $14.64^{\text {ab }}$ & $13.37^{\mathrm{bc}}$ \\
\hline FBW & \pm 0.08 & \pm 0.48 & \pm 0.76 & \pm 0. & \pm 0.70 & \pm 0.10 & \pm 0.24 \\
\hline Total & $9.16^{c}$ & $11.80^{\text {ab }}$ & $11.15^{\mathrm{ab}}$ & $11.00^{\mathrm{ab}}$ & $12.10^{\mathrm{a}}$ & $11.61^{\text {ab }}$ & $10.35^{\mathrm{bc}}$ \\
\hline WG (c & \pm 0.08 & \pm 0.46 & \pm 0.77 & \pm 0.64 & \pm 0.71 & \pm 0.09 & \pm 0.24 \\
\hline Relative growth & $302^{c}$ & $389^{\text {ab }}$ & $367^{\mathrm{ab}}$ & $365^{a b}$ & $401^{a}$ & $383^{\text {ab }}$ & $343^{b c}$ \\
\hline rate, $\mathbf{R}$ & \pm 2.88 & \pm 13.87 & \pm 25.54 & \pm 20.98 & \pm 24.43 & \pm 2.58 & \pm 8.59 \\
\hline $\begin{array}{l}\text { Specific growth } \\
\text { rate, SGR }(\% / \text { day })\end{array}$ & $\begin{array}{l}1.55^{c} \\
\pm 0.01\end{array}$ & $\begin{array}{l}1.77^{\text {ab }} \\
\pm 0.03\end{array}$ & $\begin{array}{l}1.71^{\text {ab }} \\
\pm 0.06\end{array}$ & $\begin{array}{l}1.71^{\text {ab }} \\
\pm 0.05\end{array}$ & $\begin{array}{l}1.79^{a} \\
\pm 0.05\end{array}$ & $\begin{array}{l}1.75^{\text {ab }} \\
\pm 0.01\end{array}$ & $\begin{array}{l}1.65^{b c} \\
\pm 0.02\end{array}$ \\
\hline
\end{tabular}

Within a raw, values with different superscripts are significantly different $(P<0.05)$.

The results of the present study investigated that some medicinal herbs can be effective immunostimulators (e.g. Artemisia capillaries, Astragalus radix, Massa medicata fermentata, Scutellaria radix). Their effectiveness has been demonstrated in the rearing of aquatic animals such as shrimps and fish (Dügenci et al. 2003; Jian and Wu 2004 and Yin et al., 2006). Moreover, some studies have confirmed that the application of a diet 
with herbal adjutants has a positive impact on the health and resistance of the fish, and also improves their conditions and growth rate (Lee et al., 2001; Jian and Wu 2004 and Sivaram et al., 2004). Abd El-Maksoud et al. (1999) observed that the highest weight gain of Nile tilapia (Oreochromis niloticus) fingerlings was obtained when fed with $3 \%$ marjoram leaves of the total diet. This also resulted in the best protein and energy utilizations apart from having a significant effect on body composition. On the contrary, results obtained by Abd El-Maksoud et al. (2002) demonstrated that Nile tilapia (Oreochromis niloticus) fingerlings fed diets contained $0.5-1 \%$ of chamomile flowers, Nigel seed or marjoram leaves alone showed lower performance than the control group. The differentiation between the mentioned experiment before and the present study may contribute to fish species and the levels of herbal plants tested.

Results of Table $(3)$ showed in general significant effects $(P<0.05)$ on feed utilization of tilapia hybrid fingerlings when herbal plants were added to the control diet. Fish groups fed herbal plants additives showed higher feed intake, except group fed diet $\mathrm{H}_{7}$, than the control diet. The improvements in feed intake were indicated significantly $(\mathrm{P}<0.05)$ in fish treatments fed diets supplemented at level of $150 \mathrm{mg} / \mathrm{Kg}$ of both marjoram or sage $\left(\mathrm{H}_{2} \& \mathrm{H}_{5}\right)$, respectively compared to the control group fed diet without herbal plants additives. It is noted that within the type of herbal plant, the improvement was declined when the level of herbal plant increased. In this respect, according to Mabey (1988) marjoram contains tonic and astringent bitter principles, which rouse the appetite and hence it is helpful for invalids. Sage herb when used in large amounts causes nervous irritation, convulsions and death. Hence its use is prohibited in known epileptic conditions. However, some reports suggest the toxicity and carcinogenicity of herbal reactive metabolites and/or intermediates that arise through internal metabolism.

Table 3: Feed utilization of tilapia hybrid (Oreochromis niloticus $\times 0$. aureus) fingerlings fed the experimental diets (Mean $\pm \mathrm{SE}$ ).

\begin{tabular}{|c|c|c|c|c|c|c|c|}
\hline & \multicolumn{7}{|c|}{ Experimental diets } \\
\hline \multirow[b]{2}{*}{ Item } & Control & \multicolumn{3}{|c|}{ Marjoram } & \multicolumn{3}{|c|}{ Sage } \\
\hline & $\mathrm{H}_{1}$ & $\mathrm{H}_{2}$ & $\mathrm{H}_{3}$ & $\mathrm{H}_{4}$ & $\mathrm{H}_{5}$ & $\mathrm{H}_{6}$ & $\mathrm{H}_{7}$ \\
\hline Feed intake, FI & $15.22^{\mathrm{bc}}$ & $16.30^{\mathrm{a}}$ & $16.11^{\text {ab }}$ & $15.77^{\text {ab }}$ & $16.27^{\mathrm{a}}$ & $15.73^{\text {ab }}$ & $14.78^{c}$ \\
\hline (g/fish) & \pm 0.12 & \pm 0.03 & \pm 0.46 & \pm 0.31 & \pm 0.45 & \pm 0.19 & \pm 0.19 \\
\hline Feed conversion & $1.66^{b}$ & $1.38^{\mathrm{a}}$ & $1.45^{\mathrm{a}}$ & $1.43^{\mathrm{a}}$ & $1.35^{\mathrm{a}}$ & $1.36^{\mathrm{a}}$ & $1.43^{\mathrm{a}}$ \\
\hline ratio (FCR) & \pm 0.00 & \pm 0.05 & \pm 0.06 & \pm 0.05 & \pm 0.04 & \pm 0.01 & \pm 0.01 \\
\hline Protein efficiency & $1.96^{b}$ & $2.38^{a}$ & $2.28^{\mathrm{a}}$ & $2.28^{a}$ & $2.41^{\mathrm{a}}$ & $2.41^{a}$ & $2.27^{a}$ \\
\hline ratio (PER) & \pm 0.00 & \pm 0.09 & \pm 0.09 & \pm 0.09 & \pm 0.08 & \pm 0.01 & \pm 0.02 \\
\hline Protein productive & $19.70^{b}$ & $29.90^{\mathrm{a}}$ & $28.63^{a}$ & $30.29^{a}$ & $32.01^{a}$ & $30.50^{\mathrm{a}}$ & $29.83^{\mathrm{a}}$ \\
\hline value (PPV \%) & \pm 0.02 & \pm 0.86 & \pm 2.40 & \pm 1.43 & \pm 0.87 & \pm 0.29 & \pm 0.26 \\
\hline $\begin{array}{l}\text { Fat productive } \\
\text { value (FPV \%) }\end{array}$ & $\begin{array}{l}21.59^{d} \\
\pm 0.02\end{array}$ & $\begin{array}{l}36.57^{c} \\
\pm 0.85\end{array}$ & $\begin{array}{l}37.42^{\mathrm{bc}} \\
\pm 1.36\end{array}$ & $\begin{array}{c}\mathbf{4 0 . 6 0}^{\text {ab }} \\
\pm 1.39\end{array}$ & $\begin{array}{l}44.73^{\mathrm{a}} \\
\pm 1.09\end{array}$ & $\begin{array}{c}36.15^{\mathrm{bc}} \\
\pm 0.53\end{array}$ & $\begin{array}{l}35.95^{\mathrm{c}} \\
\pm 3.55\end{array}$ \\
\hline Energy utilization & $11.50^{c}$ & $18.48^{b}$ & $17.94^{b}$ & $19.83^{\text {ab }}$ & $20.88^{a}$ & $19.22^{\text {ab }}$ & $20.35^{a}$ \\
\hline (EU \%) & \pm 0.01 & \pm 0.50 & \pm 1.15 & \pm 0.82 & \pm 0.55 & \pm 0.22 & \pm 0.87 \\
\hline
\end{tabular}

Within a raw, values with different superscripts are significantly different $(P<0.05)$.

Feed conversion ratio (FCR) and protein efficiency ratio (PER) were affected, in the same trend, by the herbal additives. Best FCR and highest 
PER were observed $(P>0.05)$ for fish groups fed $150,300 \mathrm{mg} / \mathrm{Kg}$ sage $\left(\mathrm{H}_{5}\right.$ \& $\mathrm{H}_{6}$ ) and $150 \mathrm{mg} / \mathrm{Kg}$ marjoram $\left(\mathrm{H}_{2}\right)$, respectively. Protein productive values (PPV\%) were also affected by the feed additives, where $\mathrm{H}_{5}$ and $\mathrm{H}_{6}$ followed by $\mathrm{H}_{4}$ revealed the highest figures compared with the control diet. Highest results of fat productive value (FPV\%) were obtained in fish groups fed diet $\mathrm{H}_{5}$ (sage) followed by those fed $\mathrm{H}_{4}$ (marjoram). However, fish groups fed all levels of sage and the highest level of marjoram $\left(\mathrm{H}_{4}\right)$ showed the best improvement in energy utilization, EU ( $P>0.05)$ compared to fish group fed $\left(H_{1}\right)$. It has been suggested that the herbal plants can improve the metabolism of fats and their utilization parameters (Jeong et al., 2007 and Takaoka et al., 2007). High antioxidant activity was also recognized in medicinal plants which contain polyphenols that protect and reduce cellular damage by various radicals. It is also reasonable that antioxidants in herbs contribute to the activation of immune functions for various pathogens in fish. Immunostimulating activities of herbs has been reported in other fish, such as tiger shrimp, Japanese flounder (Jeong et al., 2007), yellow croaker Pseudoscianena crocea (Jian and Wu, 2003) and greasy grouper (Sivaram et al., 2004).

Another factor that may impact the effectiveness of the herbal adjuvant as a growth stimulant might also be the period in which the supplemented diet is applied (Dügenci et al., 2003; Jian and Wu 2004 and Yin et al., 2006).With carp weighed $100 \mathrm{~g}$ the improvement in growth rate was confirmed after 30 days of the herbal supplemented diet.

The results of proximate analysis of whole body of tilapia hybrid for dry matter, protein, ether extract, ash and gross energy at the end of the study are shown in Table (4). Dry matter content was increased significantly in marjoram or sage diets than control diet, while ash content was decreased $(P<0.05)$. The protein contents in fish body were affected negatively by additive levels of herbal plants compared with control group.

Table 4: Whole body composition (\%DM) of tilapia hybrid (Oreochromis niloticus $\times 0$. aureus) fingerlings at the end of experiment (Mean \pm SE).

\begin{tabular}{|c|c|c|c|c|c|c|c|}
\hline & \multicolumn{7}{|c|}{ Experimental diets } \\
\hline \multirow[b]{2}{*}{ Item } & Control & \multicolumn{3}{|c|}{ Marjoram } & \multicolumn{3}{|c|}{ Sage } \\
\hline & $\mathrm{H}_{1}$ & $\mathrm{H}_{2}$ & $\mathrm{H}_{3}$ & $\mathrm{H}_{4}$ & $\mathrm{H}_{5}$ & $\mathrm{H}_{6}$ & $\mathrm{H}_{7}$ \\
\hline Dry $\mathrm{n}$ & $17.87^{d}$ & $22.18^{\mathrm{C}}$ & $22.34^{\mathrm{DC}}$ & $24.41^{a}$ & $23.97^{\mathrm{a}}$ & $23.01^{\mathrm{D}}$ & $22.91^{\mathrm{bc}}$ \\
\hline DVI & 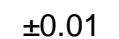 & \pm 0.08 & \pm 0.58 & \pm 0.16 & \pm 0.25 & \pm 0.07 & \pm 0.0 \\
\hline $\begin{array}{l}\text { Crude protein } \\
(\mathrm{CP} \%)\end{array}$ & $\begin{array}{l}52.11^{\mathrm{a}} \\
\pm 0.01\end{array}$ & $\begin{array}{c}51.51^{\text {abc }} \\
\pm 0.44\end{array}$ & 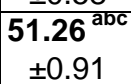 & $\begin{array}{l}49.06^{\mathrm{d}} \\
\pm 0.29\end{array}$ & $\begin{array}{c}\mathbf{5 0 . 4 1}^{\text {bcd }} \\
\pm 0.61\end{array}$ & $\begin{array}{c}50.01^{\text {cd }} \\
\pm 0.48\end{array}$ & $\begin{array}{c}51.74^{\text {ab }} \\
\pm 0.03\end{array}$ \\
\hline $\begin{array}{l}\text { Ether extract } \\
\text { (EE\%) }\end{array}$ & $\begin{array}{l}18.46^{\mathrm{d}} \\
\pm 0.01\end{array}$ & $\begin{array}{c}21.10^{\text {abc }} \\
\pm 0.23\end{array}$ & $\begin{array}{c}20.87^{\text {abc }} \\
\pm 0.48\end{array}$ & $\begin{array}{c}22.05^{\text {ab }} \\
\pm 0.09\end{array}$ & $\begin{array}{l}22.73^{\mathrm{a}} \\
\pm 0.25\end{array}$ & $\begin{array}{c}20.10^{\text {bcd }} \\
\pm 0.29\end{array}$ & $\begin{array}{l}19.70^{\text {cd }} \\
\pm 1.73\end{array}$ \\
\hline A & $\begin{array}{l}27.31^{\mathrm{a}} \\
\pm 0.01\end{array}$ & $\begin{array}{l}24.30^{\mathrm{e}} \\
\pm 0.29\end{array}$ & $\begin{array}{c}24.55^{\mathrm{de}} \\
\pm 0.09\end{array}$ & $\begin{array}{c}25.65^{\mathrm{bc}} \\
\pm 0.03\end{array}$ & $\begin{array}{c}24.85^{\mathrm{de}} \\
\pm 0.14\end{array}$ & $\begin{array}{l}25.83^{b} \\
\pm 0.34\end{array}$ & $\begin{array}{c}25.10^{\text {cd }} \\
\pm 0.12\end{array}$ \\
\hline $\begin{array}{l}\text { Gross energy } \\
\text { (Kcal GE/kg) }\end{array}$ & 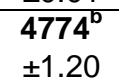 & $\begin{array}{l}5028^{\text {ab }} \\
\pm 31.32\end{array}$ & $\begin{array}{l}5001^{\text {ab }} \\
\pm 7.65\end{array}$ & $\begin{array}{c}4985^{\text {ab }} \\
\pm 1.11\end{array}$ & $\begin{array}{r}5076^{\mathrm{a}} \\
\pm 17.65\end{array}$ & $\begin{array}{r}4887^{\circ} \\
\pm 25.29\end{array}$ & $\begin{array}{l}4923^{\text {ab }} \\
\pm 89.21\end{array}$ \\
\hline
\end{tabular}

Within a raw, values with different superscripts are significantly different $(P<0.05)$.

* Fish analysis before beginning the experiment were: DM, $13.97 \%$; CP, 52.03\%; EE, $18.11 \% ; A$ 
Fish group fed diet $\mathrm{H}_{4}$ showed the lowest protein content in its whole body composition. On the other hand, ether extract and GE contents in whole fish body at the end of the experiment were significantly increased in diets contained the tested herbal plants.

The present results are in accordance with the experiments conducted by (Zakęś et al., 2001 and 2004). They obtained that, the addition of herbal supplements to commercial feed could potentially be advantageous especially in species that are less effective at assimilating high-caloric commercial feeds and that store energy as fat, especially in the viscera, such as pikeperch (Sander lucioperca, L.). On the other hand, in studies suggesting a growth-promoting effect of herbal adjuvant no differences were noted in the proximate composition of the fish bodies (Jeong et al., 2007 and Takaoka et al., 2007). Although results of Zakęś et al. (2008) did not suggest that the herbal adjuvants (Astragalus radix and Lonicera japonica) had a significant impact on the growth rate of juvenile pikeperch (Sander lucioperca L.) fish, the protein content of the fish from the dietary group fed both of the herbs was significantly higher than in the treatments fed diets supplemented with just one herb or the control group. Also, they obtained that, the herbs did not have a significant impact on the fat content in the whole fish body, such an effect was noted in the proximate composition of the viscera. On the same trend, feeding fish diets with herbal adjuvants can improve the lipid metabolism (Jeong et al., 2007) as fat is more effectively utilized as a source of energy, which means that protein ingested with the diets can be used more effectively for somatic growth.

\section{Conclusion}

According to the results obtained from the present study, it could be concluded that tilapia hybrid (Oreochromis niloticus $\times$ Oreochromis aureus) monosex fingerlings achieve increased weight gain, feed efficiency, and protein content in whole body composition by 150 and $300 \mathrm{mg} / \mathrm{kg}$ dietary additives of marjoram or sage herbs

\section{REFERENCES}

A.O.A.C. (2000). Association of Official Analytical Chemists. Official Methods of Analysis. 17 ed., Washington, D.C., USA.

Abd El Monem, A.I.; S.M.M. Shalaby and A.Y. El-Dakar (2002). Response of red tilapia to different levels of some medicinal plants by-products of black seed and roquette seed meal. Proceeding of the $1^{\text {st }}$ Scientific Conference on Aquaculture, 13-15 December 2002, El- Arish, Egypt, pp. 247-280.

Abd El-Maksoud, A.M.S.; G.E. Aboul-Fotouh; S.M. Allam and R.M. Abou Zied (1999). Effect of marjoram leaves (Majorana hortensis L. [Origanum majorana]) as a feed additive on the performance of Nile tilapia (Orechromis niloticus) fingerlings', Egyptian J. Nutritioin and Feeds, 2(1), 39-47. 
Abd El-Maksoud, A.M.S.; M.M.E. Hassouna and A.A. Ali (2002). Effect of methyltesterone on Nile tilapia fry masculinity and subsequence growth until marketing. Egypt. J. Aquat. Boil. \& Fish., 6: 91-100.

APHA (1992). Standard Methods for the Examination of Water and Waste Water. American Public Health Association. Washington, D.C., USA.

Ardo, L.; G. Yin; P. Xu; L. Varadi; G. Szigeti; Z. Jeney and G. Jeney (2008). Chinese herbs (Astragalus membranaceus and Lonicera japonica) and boron enhance the non-specific immune response of Nile tilapia (Oreochromis niloticus) and resistance against Aeromonas hydrophila. Aquaculture, 275: 26-33.

Boyd, C.E. (1990). Water quality ponds for aquaculture. Agricultural Experiment Station, Auburn University, Auburn, Alabama. 482 pp.

Cherevatyî, V.S.; T.N. Vashhenko; G.Z. Shishkov (1980). Comparative evaluation of the antibacterial action of different extracts from Salvia officinalis. Rastitel'nye Resursy. 16: 137-139.

Citarasu, T.; K.V. Ramalingam; R.R.J. Sekar; M.M. Babu and M.P. Marian (2003). Influence of the antibacterial herbs, Solanum trilobatum and rographis paniculata and Psoralea coylifolia on the survival, growth and bacterial load of Penaeus monodon post larvae. Aquac. Int., 11: 581595.

Citarasu, T.; M.M. Babu, R.R.J. Sekar and M.P. Marian (2002). Developing Artemia enriched herbal diet for producing quality larvae in Penaeus monodon, Fabricius. Asian Fish. Sci., 15: 21-32.

Dauncan, D. (1955). Multiple range and Multiple (F) tests. Biometrics, 11: 1-2.

Dügenci, S.K., N. Arda and A. Candan (2003). Some medicinal plants as immunostimulant for fish. J. of Ethnopharmacology, 88: 99-106.

El-Dakar, A.Y.; G.D.I. Hassanien; Seham S. Gad and S.E. Sakr (2008). Use of dried basil leaves as a feeding attractant for hybrid tilapia, Oreochromis niloticus $\times$ Oreochromis aureus, fingerlings. Med. Aquacult. J., 1 (1): 35-44.

El-Dakar, A.Y.; S.M.M. Shalaby and I.P. Saoud (2007). Assessing the use of a dietary probiotic/prebiotic as an enhancer of spinefoot rabbitfish Siganus rivulatus survival and growth. Aquacult. Nut, 13(6):407-412.

El-Dakar, A.Y.; M.M. Shymaa; S.M.M. Shalaby and M.M., Khalafala (2005). Use of spices as feeding stimulants in diets of marine shrimp, Penaeus japonicus. Egyptian J. of Nutrition and Feeds, 8 (1): 1065-1076.

El-Dakar, A.Y.; G.D.I. Hassanien; Seham S. Gad and S.E. Sakr (2004a). Use of Medical and Aromatic Plants in Fish Diets: I. Effect of dried marjoram leaves on performance of hybrid tilapia Oreochromis niloticus $x$ Oreochromis auraus, fingerlings. J. of the Egyptian Acad. Society for Environ. Develop. (B. Aquaculture), 5(1): 67-83.

El-Dakar, A.Y.; G.D.I. Hassanien; Seham S. Gad and S.E. Sakr (2004b). Use of medical and aromatic plants in fish diets: 2. Effect of dried basil leaves on performance of hybrid tilapia Oreochromis niloticus $\times$ Oreochromis auraus, fingerlings $3^{\text {rd }}$ Int. Conf. on Anim. Production and Health in Semi-Arid Areas, Suez Canal Univ. 
El-Ghorab, A.H.; A.F. Mansour and K.F. El-Massry (2004). Effect of extraction methods on the chemical composition and antioxidant activity of Egyptian marjoram (Majorana hortensis Moench). Flav. Fragr. J. 19: 54-61.

Evans, W. (1996). Trease and Evan's Pharmacognosy, $14^{\text {th }}$ ed. WB Saunders, London, p.780.

Farag, R.S.; F.L. Salem; A.Z.M.A. Badei and D.E. Hassanein (1986). Biochemical studies on the essential oil of some medicinal plants. Fette Seifen Anstrichmittel. 88: 69-72.

Gotez, F.W.; D.B. Iliev; L.A.R. McCauley; C.Q. Liarte, L.B. Tort; J.V. Planas and S. MacKenzie (2004). Analysis of genes isolated from lipopolysaccharid estimated rainbow trout (Oncorhynchus mykiss) macrophages. Mol. Immunol., 41: 1199-1210.

Hartweel, J.L. (1969). Plants used against cancer. A survey. Lioydia 32: 247296.

Hohmann, J.; I. Zupko; D. Redei; M. Csanyi; G. Falkay; I. Mathe and G. Janicsak (1999). Protective effects of the aerial parts of Salvia of cinalis, Melissa Of cinalis, and Lavandula angustifolia and their constituents against enzyme-dependent and enzyme-independent lipid peroxidation. Planta Medica, 65: 576-578.

Jeong, J. S.-C.; G.-S. Im; S.-W. Lee; J.-H. Yoo. and K. Takii (2007). Dietary medicinal herbs improve growth performance, fatty acid utilization, and stress recovery of Japanese flounder. Fisheries Science 73, 70-76.

Jian, J. and Z. Wu (2004). Influences of traditional Chinese medicine on nonspecific immunity of Jian carp (Cyprinus carpio var. Jian). Fish and Shellfish Immunology 16: 185-191.

Jian, J. and Z. Wu (2003). Effect of traditional Chinese medicine on nonspecific immunity and disease resistance of larvae of yellow croaker Pseudosciaena crocea (Richardson). Aquaculture, 218: 1-9.

Jobling, M. (1983). Effect of feeding frequency on food intake and growth of Arctic charr, Salvelinus alpinus (L.). J. Fish. Biol., 23: 177-185.

Lee, S.M.; C.S. Park and D.S. Kim (2001). Effects of dietary herbs on growth and body composition of juvenile abalone, Haliotis discus hannai. Journal of the Korean Fishery Society, 34:570-575.

Mabey R. (1988). The Complete New Herbal - A Practical Guide to Herbal Gardening, Elm Tree Books, London.

Omidbeygi, R. (1997). Usage and Production of Medical Plant, Vol. 2. Tarahan Nashre Press, Iran, pp. 210-216.

Pachanawan, A.; P. Phumkhachorn and P. Rattanachaikunsopon (2008). Potential of Psidium guajava supplemented fish diets in controlling aeromonas hydrophila infection in tilapia (Oreochromis niloticus). J. Biosci. Bioeng., 106: 419-424.

Pearson, D.A.; E.N. Frankel and N. Edwin (1997). Inhibition of endothelial cell-mediated oxidation of low-density lipoprotein by rosemary and plant phenolics. Journal of Agricultural and Food Chemistry, 45: 578582. 
Pruthi, J.S. (1980). Spice and condiments. Chemistry, Microbiology, Technology, Academic Press, New York, pp 221.

Rao, Y.V.; B.K. Das; J. Pradhan and R. Chakrabarti (2006). Effect of Achyranthes aspera on the immunity and survival of Laboe rohita infected with Aeromonas hydrophlia. Fish. Shellfish Immunol., 20: 263273.

Sakr, S.E. (2003). Studies on feeding attractant for fish. M.Sc. Thesis. Fac. of Environmental Agric. Sci., Suez Canal Univ., Egypt.

SAS 2002. SAS software version 8. SAS Institute Inc., Cary, North Carolina. United States of America.

Shalaby, S.M.M. (2004). Response of Nile tilapia (Oreochromis niloticus) fingerlings to diets supplemented with different levels of fenugreek seeds (Hulba). Mansoura Univ. J. of Agric. Sci., 29 (5): 2231-2242.

Shalaby, S.M.M.; A.I. Abd El Monem, and A.Y. El-Dakar (2003). Enhancement of growth performance, feed and nutrient utilization, of Nile tilapia (Oreochromis niloticus) using of licorice roots (Erksous) as a feed attractive. J. of the Egyptian Acad. Soc. for Environment (B. Aquaculture), 4(2): 119-142.

Sivaram, V.; M.M. Babu; G. Immanuel; S. Murugadass; T. Citarasu and M.P. Marian (2004). Growth and immune response of juvenile greasy groupers (Epinephelus tauvina) fed with herbal antibacterial active principle supplemented diets against Vibrio infections. Aquaculture 237: 9-20.

Siwicki, A.K.; Ł.Z. Zakęś; J.C. Fuller; S. Nissen; S. Trapkowska; E. Gł ạbski; A. Kowalska, K. Kazuń and E. Terech-Majewska (2006). Influence of $\beta$ hydroxy- $\beta$-methylbutyrate on nonspecific humoral defense mechanisms and protection against furunculosis in pikeperch (Sander lucioperca). Aquaculture Res., 37:127-131.

Tainter D.R. and A.T. Grenis (1993). Spices and Seasonings: A Food Technology Hand Book, VCH Publishers, Inc. New York.

Takaoka, J. S.-C.O.; G.-S. Jeong; S.-W. Lee; K. Ishimaru; M. Seoka and K. Takii (2007). Dietary medicinal herbs improve growth and non- specific immunity of red sea bream Pagrus major. Fisheries Science 73, 63-69.

Yin G.; G. Jeney; T. Racz; P. Xu; X. Jun and Z. Jeney (2006). Effect of two Chinese herbs (Astragalus radix and Scutelaria radix) on non-specific immune response of tilapia, Oreochromis niloticus. Aquaculture, 253: 39-47.

Zargari, A. (1997). Medicinal Plant, vol. 4. Tehran Univ. Press, Iran, pp. 5964.

Zakęś , Ł.Z.; A. Kowalska; K.D. Zakęś; G. Jeney and Z. Jeney (2008). Effect of two medicinal herbs (Astragalus radix and Lonicera japonica) on the growth performance and body composition of juvenile pikeperch [Sander lucioperca (L.)]

Zakęś, Ł.Z.; A. Przybł; M. Woźniak; M. Szczepkowski and J. Mazurkiewicz (2004). Growth performance of juvenile pikeperch, Sander lucioperca (L.) fed graded levels of dietary lipids. Czech J. Animal Science 49: 156-163. 
El-Kholy, Kh. F.

Zakęś, Ł.Z.; M. Szkudlarek; M. Woźniak; A. Karpinński and K. Demska Zakęś (2001). Effect of dietary protein: fat ratios on metabolism, body composition and growth of juvenile pikeperch, Stizostedion lucioperca (L.). Czech J. Animal Science, 46: 27-33.

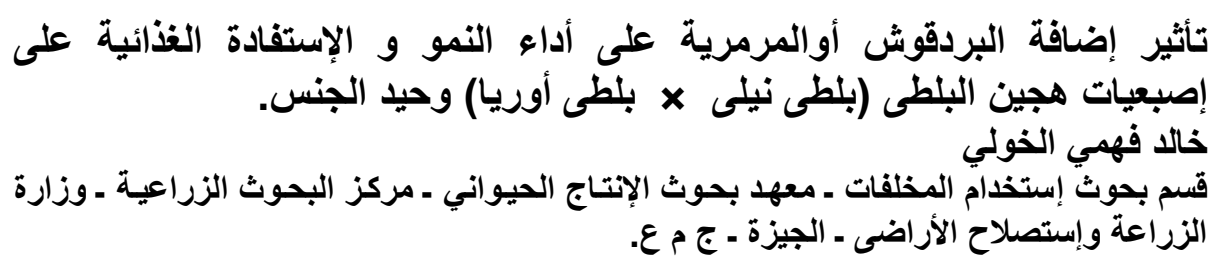

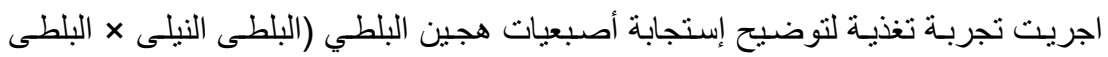

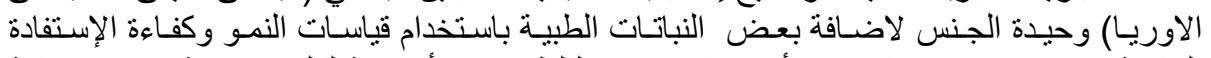

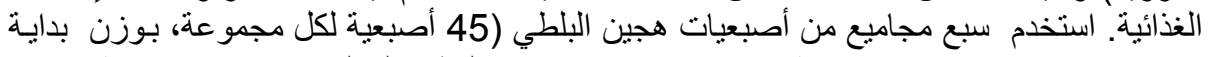

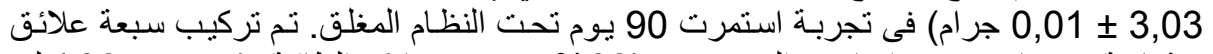

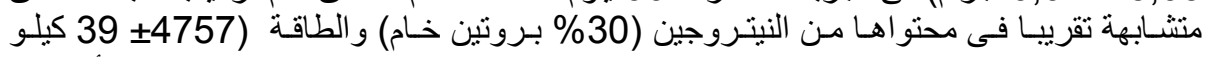

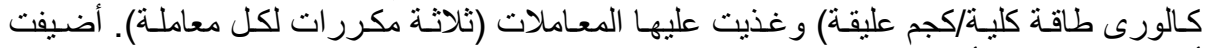

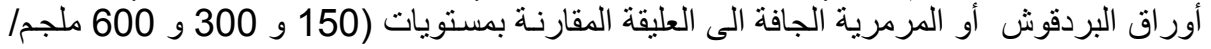

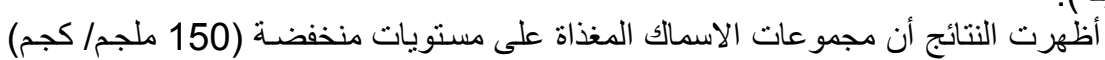
كجم عليقة).

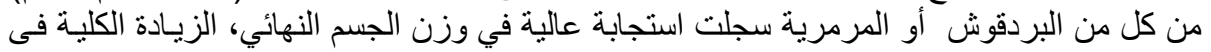

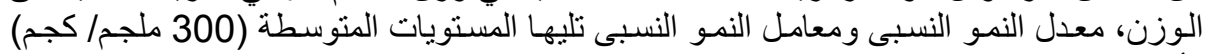

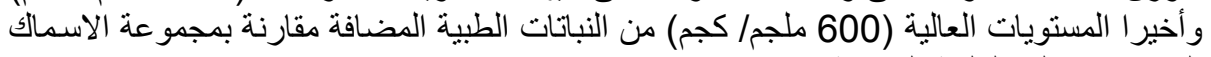
التى تغذت على العليقة الدقارنة.

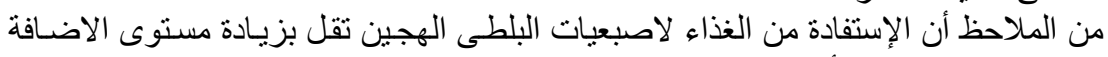

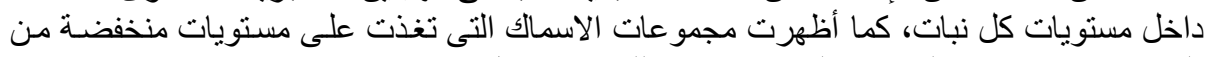

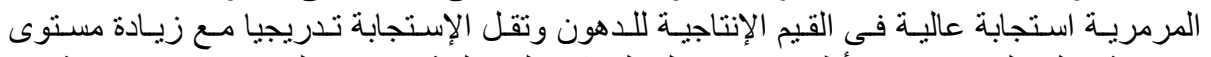

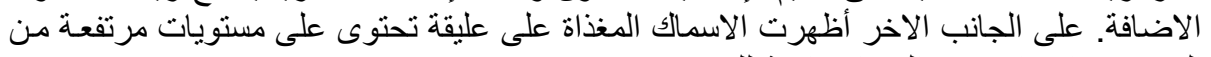
البردقوش انخفاض في القيم الانتاجية للإهون.

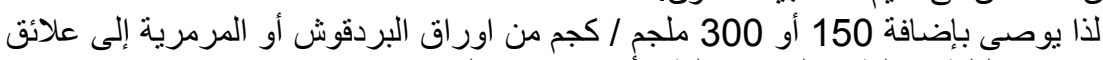
إصبعيات هجين البلطى (بلطى نيلى × بلطى أوريا) وحيد الجنس.

كلية الزراعة - جامعة المنصورة كلية الزراعة - جامعة الفيوم
قام بتحكيم البحث

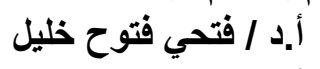

أ.د / محمد محمد السعيد حتونة فلئ 